\title{
Phase Equilibrium Diagram for Electric Arc Furnace Slag Optimization in High Alloyed Chromium Stainless Steelmaking
}

\author{
Marcus Kirschen ${ }^{1, *}$, In-Ho Jung ${ }^{2}$ (1) and Gernot Hack1 ${ }^{3}$ \\ 1 Thermal Process Engineering, University of Bayreuth, Universitätsstrasse 30, D-94557 Bayreuth, Germany \\ 2 Department of Materials Science and Engineering, Seoul National University, 1 Gwanak-ro, Gwanak-Gu, \\ Seoul 08826, Korea; in-ho.jung@snu.ac.kr \\ 3 RHI MAGNESITA, Magnesitstrasse 2, A-9700 Leoben, Austria; gernot.hackl@rhimagnesita.com \\ * Correspondence: marcus.kirschen@uni-bayreuth.de; Tel.: +49-921-55-7486
}

Received: 25 May 2020; Accepted: 18 June 2020; Published: 20 June 2020

\begin{abstract}
The electric arc furnace (EAF) process for steelmaking of $\mathrm{Cr}$ and Ni high alloyed stainless steel grades differs significantly from the steelmaking process of carbon steel due to the special raw materials and generally lower oxygen consumption. The special slag chemistry in the EAF process affects slag foaming and refractory wear characteristics due to an increased content of $\mathrm{CrO}_{\mathrm{x}}$. A special slag diagram is presented in order to improve monitoring and control of slag compositions for $\mathrm{Cr}$ alloyed heats, with special focus on saturation to $\mathrm{MgO}$ periclase and dicalcium silicate $\mathrm{C}_{2} \mathrm{~S}$ in order to minimize $\mathrm{MgO}$ losses from the refractory lining and to improve slag refining capability by avoidance of stable $\mathrm{C}_{2} \mathrm{~S}$. With the same diagram different EAF process strategies can be efficiently monitored, either at elevated $\mathrm{CaO}$ and basicity with lower spinel concentration and more liquid process slags near $\mathrm{C}_{2} \mathrm{~S}$ saturation or at lower $\mathrm{CaO}$ content and basicity with increased spinel concentration and stiffer slags at $\mathrm{MgO}$ saturation but certainly no $\mathrm{C}_{2} \mathrm{~S}$ stability. Examples for three industrial EAFs are given.
\end{abstract}

Keywords: electric arc furnace; stainless steel making; slag modelling; phase diagram

\section{Introduction}

Some 52.2 million tons of high alloyed and stainless steel grades were produced in 2019, i.e., approximately $2.8 \%$ of total steel production with an increasing trend due to global market demands. The modern production process is based on melting of steel scrap and alloys in an electric arc furnace (EAF) and subsequent decarburization and refinement of the molten metal in an argon-oxygen decarburization (AOD) converter or more rarely by vacuum oxygen decarburization (VOD) treatment. In a few cases, raw steel is melted from scrap in the EAF and liquid or solid Cr-alloys are added at the converter.

Production of high-alloyed $\mathrm{Cr}$ or $\mathrm{Cr}-\mathrm{Ni}$ molten metal in the EAF introduces additional metallurgical constraints to EAF process conditions. As oxidation of $\mathrm{C}$ and $\mathrm{Cr}$ in the molten metal occurs at very similar oxygen activities, special care is needed to minimize $\mathrm{Cr}$ losses, especially during oxygen injection in the EAF. Cr oxidation increases at depleted $C$ concentration. The amount of injected oxygen in the EAF is usually lower than $15 \mathrm{~m}^{3} / \mathrm{t}$ compared to levels of between 25 and $40 \mathrm{~m}^{3} / \mathrm{t}$ for EAF carbon steelmaking, and up to $50 \mathrm{~m}^{3} / \mathrm{t}$ for hot metal refining in LD converters. As consequence, the mixing of the steel melt in the EAF is insufficient and concentration gradients of $\mathrm{C}, \mathrm{Si}$ and $\mathrm{Cr}$ may occur in the melt volume. Temperature gradients caused by low bath movement and formation of $(\mathrm{Mn}, \mathrm{Mg}) \mathrm{Cr}_{2} \mathrm{O}_{4}$ spinels may contribute to unwanted bottom build-up of the EAF hearth. Active mixing of the melt 
volume by inert gas bottom stirring or electromagnetic stirring is state-of-the art for the majority of EAFs for stainless steel grades.

The ratio of the relevant $\mathrm{Cr}$ oxides in the slag, $\mathrm{CrO}$ and $\mathrm{Cr}_{2} \mathrm{O}_{3}$, depends on temperature and oxygen partial pressure. In this paper, we use $\mathrm{Cr}_{2} \mathrm{O}_{3}$ as a synonym for both $\mathrm{Cr}$ oxides in the slag, due to the dominance of $\mathrm{Cr}_{2} \mathrm{O}_{3}$ species at low oxygen partial pressure in the molten metal. An option to control $\mathrm{Cr}$ oxidation and to decrease $\mathrm{Cr}$ losses in the EAF is by keeping elevated $\mathrm{C}$ and $\mathrm{Si}$ levels in the steel melt by decreased oxygen injection [1] and mixing of the steel melt with the $\mathrm{Cr}_{2} \mathrm{O}_{3}$-bearing slag during tapping. High slag basicity, and pronounced mixing dynamics during tapping via spout is known to improve $\mathrm{Cr}_{2} \mathrm{O}_{3}$ reduction [2]. In case of elevated final $\mathrm{Cr}_{2} \mathrm{O}_{3}$ concentrations, reducing agents as $\mathrm{FeSi}$, $\mathrm{C}$, or $\mathrm{Al}$ may be added before tapping in order further reduce $\mathrm{Cr}_{2} \mathrm{O}_{3}$ and to liquefy the oversaturated stiff slag by lowering the basicity of slag. Procedures for the optimum $\mathrm{Cr}$ recovery are still under discussion. For example, the combination of $\mathrm{FeSi}$ and carbon as reducing agents have been shown the best results on final $\mathrm{Cr}_{2} \mathrm{O}_{3}$ content of the slag [3]. Mees, however, found best efficiency of $\mathrm{Cr}_{2} \mathrm{O}_{3}$ reduction with $\mathrm{Al}$ addition [4]. In the 2-step (duplex) stainless steelmaking process, the remaining carbon levels after EAF tapping are further decreased in the AOD converter by submerged injection of oxygen, which is later diluted with inert gases in order to control formation of $\mathrm{Cr}_{2} \mathrm{O}_{3}$ by lowering oxygen activity in the steel melt and slag. In the VOD, decarburization at controlled $\mathrm{Cr}_{2} \mathrm{O}_{3}$ formation is achieved by inert gas stirring at decreased atmosphere pressure.

The $\mathrm{Cr}_{2} \mathrm{O}_{3}$ levels in the EAF slag affect significantly the process conditions: due to the low $\mathrm{Cr}_{2} \mathrm{O}_{3}$ solubility in basic EAF slag, the precipitation of $\mathrm{Cr}_{2} \mathrm{O}_{3}$-bearing solids occurs and results in an increase of effective slag viscosity. High slag viscosity and lower amounts of $\mathrm{CO}$ gas due to restricted oxygen injection inhibit efficient slag foaming [1]. Chosen slag composition is often at basicity $\left(\mathrm{CaO} / \mathrm{SiO}_{2}\right)<1.5$ in order to increase $\mathrm{Cr}_{2} \mathrm{O}_{3}$ activity, but optimum basicity for foaming stainless steelmaking slag is in the range of 1.5 to 1.6 [5]. The resulting lower efficiency of energy transfer from the arc to the molten metal is one reason for the generally higher specific electrical energy demand for stainless steel steelmaking.

Remaining $\mathrm{Cr}_{2} \mathrm{O}_{3}$ content in the glass phase of the cooled slag restricts significantly the utilization of stainless steelmaking slag as the construction or landfilling materials due to environmental impact by $\mathrm{Cr}^{\mathrm{VI}}$ leaching. Controlling the chemical composition of the slag at tapping is one option to fix the $\mathrm{Cr}$ components in $(\mathrm{Mn}, \mathrm{Mg}) \mathrm{Cr}_{2} \mathrm{O}_{4}$ spinels [6,7]. Stability of $\mathrm{Cr}$ spinels may be further increased in the form of $(\mathrm{Mn}, \mathrm{Mg}, \mathrm{Fe})(\mathrm{Cr}, \mathrm{Al})_{2} \mathrm{O}_{4}$ by addition of $\mathrm{Al}_{2} \mathrm{O}_{3}$ [8] and $\mathrm{FeO}$ [9].

Reduction of $\mathrm{Cr}$-rich slags and dusts by coke has been tested on a pilot scale in a separate shaft furnace or a bottom-blown converter [10], however with limited commercial success due to additional heat requirements for slag treatment.

Whereas dicalcium silicate $\left(2 \mathrm{CaO} \cdot \mathrm{SiO}_{2}, \mathrm{C}_{2} \mathrm{~S}\right.$ or larnite) is not stable in EAF slags for carbon-steelmaking due to the high concentration of $\mathrm{FeO}$ in slag (typically, $15 \%$ to $35 \% \mathrm{FeO}$ ), a $\mathrm{C}_{2} \mathrm{~S}$ phase may be stably formed in stainless steelmaking slags due to low $\mathrm{FeO}(<5 \%)$ and addition of $\mathrm{FeSi}$ as $\mathrm{Cr}_{2} \mathrm{O}_{3}$ reducing agent. $\mathrm{C}_{2} \mathrm{~S}$ in the slags after tapping, however, cause the disintegration of the solidified slag, mainly due to its $\beta$ to $\gamma-\mathrm{C}_{2} \mathrm{~S}$ phase transformation with approximately $12 \%$ volume expansion. Secondary slag treatment with elevated cooling rate $>5 \mathrm{~K} / \mathrm{s}$, or borate addition to the slag was proposed to stabilize the $\beta-C_{2} S$ phase and to avoid the disintegration [11]. However, control of the proper slag chemical composition before and at tapping to avoid the $\mathrm{C}_{2} \mathrm{~S}$ formation is a cost-efficient strategy in order to increase the valorisation of the stainless steel slag.

The chemical composition of EAF slags is usually monitored by sampling and plotting the analysis results in simplified diagrams that are widespread for carbon steelmaking, e.g., [1,12]. Formation of $\mathrm{C}_{2} \mathrm{~S}$ should be carefully monitored in order to improve valorisation of the stainless steelmaking slags at low $\mathrm{FeO}$. Although the slag chemistry is very important to improve the refractory life time and valorisation of stainless steelmaking slag, no comparable tools exist for stainless steelmaking slags due to considerably more complex phase relations at low $\mathrm{FeO}$ concentration in the $\mathrm{Cr}_{2} \mathrm{O}_{3}$-bearing system.

In the present study, we will demonstrate that the multicomponent phase diagrams calculated from FactSage thermodynamic software [13] are very valuable for the purpose of monitoring stainless 
slag chemistry. The plant data from three different EAF operations will be compared with the calculated diagrams and the impact of the slag chemistry to operation and valorisation of slag recycling will be discussed.

\section{EAF Slag Characteristics at High Cr Steel Melts}

EAF slags for melting of $\mathrm{Cr}$ stainless steel grades are based on addition of lime (and sometimes dololime or clinker) and characterized by varying $\mathrm{Cr}_{2} \mathrm{O}_{3}$ concentrations up to 20 wt. \%. $\mathrm{As}^{\mathrm{Cr}_{2} \mathrm{O}_{3}}$ saturation in the slag is already achieved at few wt.\%, these slags are often heavily over-saturated with $\mathrm{Cr}_{2} \mathrm{O}_{3}$ and/or $\mathrm{MgO}$-bearing solids and therefore difficult to foam. Increasing the typical slag basicity from 1.2-1.5 to 1.5-1.6 increases the foaming index for stainless slags [14]. Typical mean slag compositions at tapping stage from three modern stainless steel EAFs are given in Table 1 and Figure 1. As the EAF tapping process contributes to $\mathrm{Cr}_{2} \mathrm{O}_{3}$ recovery from the slag and adjusts slightly the slag basicity, the slag samples have been taken from the transport ladle shortly after tapping. Slag analysis have been provided by plant laboratory with standardized equipment.

Table 1. Average slag compositions at the tapping stage of three EAFs for stainless steel production (in wt.\%).

\begin{tabular}{cccccccccccc}
\hline EAF & $\mathbf{M g O}$ & $\mathrm{CaO}$ & $\mathbf{F e O}$ & $\mathrm{Al}_{2} \mathrm{O}_{3}$ & $\mathrm{SiO}_{2}$ & $\mathbf{M n O}$ & $\mathrm{Cr}_{2} \mathrm{O}_{3}$ & $\mathrm{TiO}_{2}$ & Total & \multicolumn{2}{c}{ Basicity } \\
\hline 1 & 14.9 & 33.8 & 1.47 & 6.01 & 32.5 & 3.55 & 5.94 & 1.73 & 100.0 & $1.04^{1}$ & $1.26^{2}$ \\
2 & 7.4 & 43.0 & n.a. & 4.34 & 31.4 & n.a. & 7.19 & 1.30 & 94.7 & $1.37^{1}$ & $1.41^{2}$ \\
3 & 10.2 & 39.3 & 1.47 & 4.65 & 30.4 & 2.78 & 9.05 & 1.33 & 99.2 & $1.31^{1}$ & $1.41^{2}$ \\
$4[5]^{3}$ & 3.08 & 44.4 & 2.29 & 5.64 & 28.3 & 2.69 & 10.13 & n.a. & 96.5 & $1.57^{1}$ & $1.40^{2}$ \\
$5[14]$ & 7.0 & 47.4 & 1.2 & 4.6 & 31.7 & 2.3 & 4.7 & 0.8 & 99.7 & $1.51^{1}$ & $1.50^{2}$ \\
\hline \multicolumn{7}{c}{${ }^{1}$ basicity $\mathrm{CaO} / \mathrm{SiO}_{2},{ }^{2}$ basicity $(\mathrm{CaO}+\mathrm{MgO}) /\left(\mathrm{SiO}_{2}+\mathrm{Al}_{2} \mathrm{O}_{3}\right),{ }^{3}$ at EAF before tapping, n.a.: not available. }
\end{tabular}

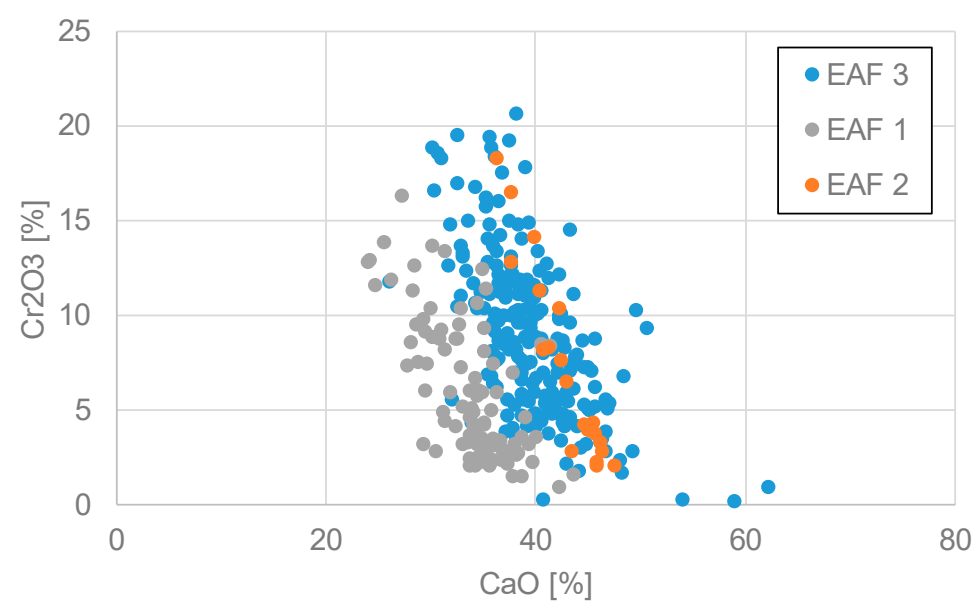

Figure 1. Variation of the $\mathrm{Cr}_{2} \mathrm{O}_{3}$ concentration in stainless steel slags with $\mathrm{CaO}$ content at tapping.

$\mathrm{FeO}$ content is low due to low Fe activity in ferrochromium melts. Average $\mathrm{Cr}_{2} \mathrm{O}_{3}$ content ranges from 6 to $9 \%, \mathrm{CaO}$ from 34 to $43 \%$ (Table 1). $\mathrm{Cr}_{2} \mathrm{O}_{3}$ concentration for all three cases is inversely proportional to $\mathrm{CaO}$ concentration (Figure 1) which can be explained by the increase in $\mathrm{Cr}_{2} \mathrm{O}_{3}$ activity coefficient with increasing basicity, i.e., either $\mathrm{CaO} / \mathrm{SiO}_{2}[15]$ or $(\mathrm{CaO}+\mathrm{MgO}) /\left(\mathrm{SiO}{ }_{2}+\right.$ $\mathrm{Al}_{2} \mathrm{O}_{3}$ ) [16]. No significant correlation was found between $\mathrm{CaO}$ and $\mathrm{MgO}$ or $\mathrm{SiO}_{2}$. Based on $\mathrm{CrO}_{x}$ activity measurements in the system $\mathrm{CaO}-\mathrm{SiO}_{2}-\mathrm{CrO}_{\mathrm{x}}$, slag basicity at 1.37 was recommended for the optimum decarburization at high $\mathrm{CrO}_{x}$ activity [15] with matches with average basicity of EAF 2 and 3 (Table 1). $\mathrm{Al}_{2} \mathrm{O}_{3}$ does not significantly affect $\mathrm{Cr}_{2} \mathrm{O}_{3}$ activity coefficient at typical slag compositions [16].

The average basicity $\mathrm{CaO} / \mathrm{SiO}_{2}$ after $\mathrm{FeSi}$ addition at tapping is in the range 1.0 to 1.4 , in order to minimize $\mathrm{Cr}_{2} \mathrm{O}_{3}$ formation by high $\mathrm{Cr}_{2} \mathrm{O}_{3}$ activity in the slag. Lower basicity at tapping, e.g., by $\mathrm{FeSi}$ addition, improve mixing with steel melt at tapping. Concerning the $\mathrm{Cr}$ leaching of the solidified slag 
on the other hand, basicity at 1.5 that has been examined as the optimum basicity for $\mathrm{Cr}_{2} \mathrm{O}_{3}$ bound in spinel with minimum $\mathrm{Cr}$ leaching [7]. Basicity $<1.5$, however, facilitates the growth of spinels [5] and increases the enrichment ratio of $\mathrm{Cr}_{2} \mathrm{O}_{3}$ in the spinels [17].

The decreasing $\mathrm{Cr}_{2} \mathrm{O}_{3}$ with $\mathrm{CaO}$ concentration indicates the reduction of $\mathrm{Cr}_{2} \mathrm{O}_{3}$ with lime addition, i.e., increased $\mathrm{Cr}_{2} \mathrm{O}_{3}$ activity at high basicity as shown in thermodynamic simulations of the stainless steel production process for a $110 \mathrm{tEAF}$ [18]. These simulations have been performed with FactSage [13]. FactSage contains the database validated for the $\mathrm{CaO}-\mathrm{MgO}-\mathrm{Al}_{2} \mathrm{O}_{3}-\mathrm{CrO}-\mathrm{Cr}_{2} \mathrm{O}_{3}$ system $[19,20]$ with experimental results on phase relations of periclase, $(\mathrm{Cr}, \mathrm{Al})_{2} \mathrm{O}_{3}, \mathrm{Mg}(\mathrm{Cr}, \mathrm{Al})_{2} \mathrm{O}_{4}$ spinel, $\mathrm{C}_{2} \mathrm{~S}$ and oxide liquid in both oxidizing and reducing conditions.

\section{Modelling}

\subsection{FactSage and Database}

FactSage thermodynamic software 7.3 version contains many thermodynamic databases for pyrometallurgical applications. For the stainless steelmaking, FACTPS pure substance compound database, FTOxid database and FSStel database (or FTmisc-FeLq database) can be used. In particular, the FTOxid database contains many large solution phases. For example, oxide solution phases important for the present stainless steelmaking process calculations are available in the database:

(i) Liquid Slag: $\mathrm{CaO}-\mathrm{MgO}-\mathrm{SiO}_{2}-\mathrm{Al}_{2} \mathrm{O}_{3}-\mathrm{FeO}-\mathrm{Fe}_{2} \mathrm{O}_{3}-\mathrm{MnO}-\mathrm{Mn}_{2} \mathrm{O}_{3}-\mathrm{CrO}-\mathrm{Cr}_{2} \mathrm{O}_{3}$-S-P-F-etc.

(ii) Spinel phase: $(\mathrm{Mg}, \mathrm{Fe}, \mathrm{Mn}, ..)[\mathrm{Cr}, \mathrm{Al}, \mathrm{Fe}, . .]_{2} \mathrm{O}_{4}$

(iii) Monoxide phase: $\mathrm{MgO}-\mathrm{CaO}-\mathrm{FeO}-\mathrm{MnO}$ rocksalt phase with a small solubility of $\mathrm{Al}_{2} \mathrm{O}_{3}, \mathrm{Cr}_{2} \mathrm{O}_{3}$, etc.

(iv) Dicalcium silicate phase: $\mathrm{Ca}_{2} \mathrm{SiO}_{4}$-rich solution phase, $(\mathrm{Ca}, \mathrm{Mg}, \mathrm{Fe}, \mathrm{Mn})_{2} \mathrm{SiO}_{4}$ solid solution

(v) Corundum phase: $(\mathrm{Cr}, \mathrm{Al}, \mathrm{Fe})_{2} \mathrm{O}_{3}$

(vi) Olivine phase: $(\mathrm{Mg}, \mathrm{Mn}, \mathrm{Fe}, \mathrm{Ca})_{2} \mathrm{SiO}_{4}$ solid solution

The details of the thermodynamic database can be found elsewhere [21] and the most recent information is available on the FactSage website (www.factsage.com).

\subsection{Modelling of $\mathrm{Cr}$-Bearing Slags}

Thermodynamic calculations based on phase equilibrium approach with FactSage [13] have been applied in previous studies in order to model the evolution of the process slag in stainless steelmaking [18]. Simulation results reproduced the observed slag microstructures [22]. The main phases during the second half of the EAF process are $\mathrm{Mg}(\mathrm{Cr}, \mathrm{Al})_{2} \mathrm{O}_{4}$ spinel, calcium silicates $\left(\mathrm{C}_{2} \mathrm{~S}, \mathrm{C}_{3} \mathrm{~S}\right)$ and oxide liquid depending on slag temperature. The oxygen partial pressure was increasing with melting time and finally in the range of $\mathrm{P}\left(\mathrm{O}_{2}\right)=10^{-9}$ atm with good prediction of the tapped steel composition [9].

Cr-bearing slags from the AOD converter have been successfully modelled with phase equilibrium calculations showing equilibrium of $\mathrm{MgCr}_{2} \mathrm{O}_{4}$ spinel solid solution and $\mathrm{C}_{2} \mathrm{~S}$ with the oxide liquid at tapping [6]. An updated database has been validated with new phase equilibrium data in the Cr-bearing slag system [23].

The phase equilibrium diagrams in the system $\mathrm{CaO}-\mathrm{SiO}_{2}-\mathrm{MgO}-\mathrm{Al}_{2} \mathrm{O}_{3}-\mathrm{Cr}_{2} \mathrm{O}_{3}$ at temperatures from $1500{ }^{\circ} \mathrm{C}$ to $1800{ }^{\circ} \mathrm{C}$ are calculated in Figure 2 using FactSage [13]. Both $\mathrm{Al}_{2} \mathrm{O}_{3}$ and $\mathrm{Cr}_{2} \mathrm{O}_{3}$ are fixed to be $5 \mathrm{wt} . \%$, which are corresponding with typical compositions of EAF slags for stainless steelmaking in Table 1. Oxygen partial pressure was set to be $10^{-9} \mathrm{~atm}$ for the calculations following the preceding studies $[18,20,23]$. Cr can change its oxidation state between +2 and +3 in both solid and liquid state depending on the oxygen partial pressure. Therefore, the proper oxygen partial pressure for the target process is important in the phase diagram calculations. As the final period of the EAF process with low $\mathrm{Cr}_{2} \mathrm{O}_{3}$ content is the most interesting for the $\mathrm{C}_{2} \mathrm{~S}$ stability in the tapped slag, the phase assemblages were calculated for the $\mathrm{CaO}-\mathrm{MgO}-\mathrm{SiO}_{2}-5 \% \mathrm{Al}_{2} \mathrm{O}_{3}-5 \% \mathrm{Cr}_{2} \mathrm{O}_{3}$ at $\mathrm{P}\left(\mathrm{O}_{2}\right)=10^{-9}$ atm in this study. 


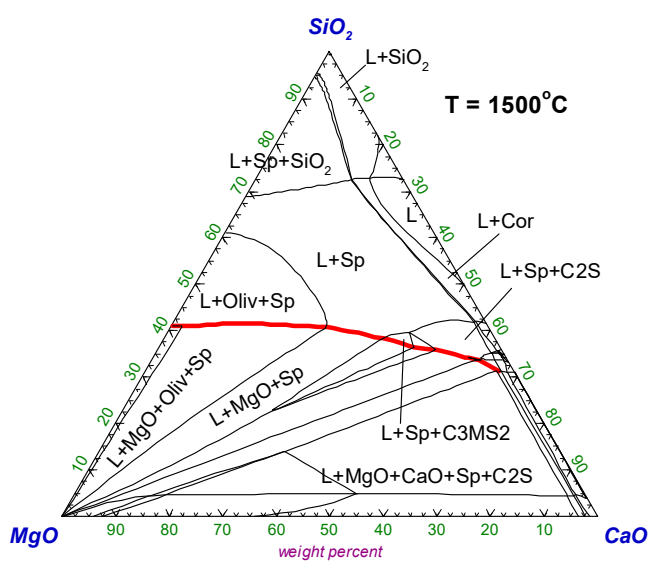

(a)

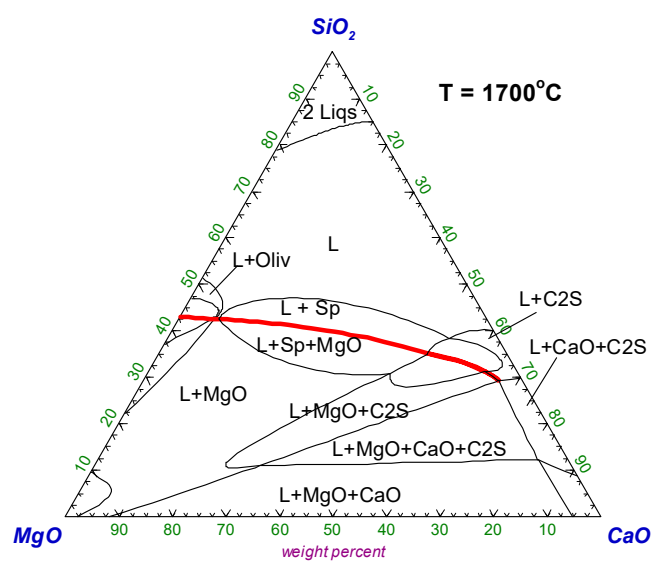

(c)

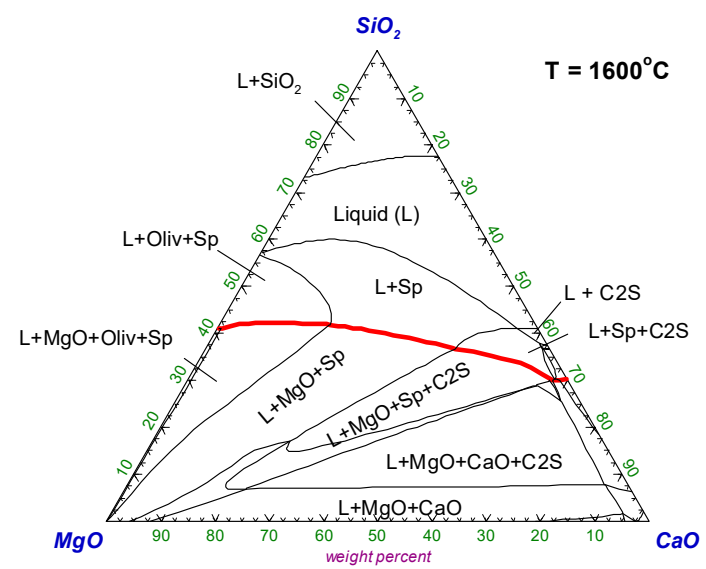

(b)

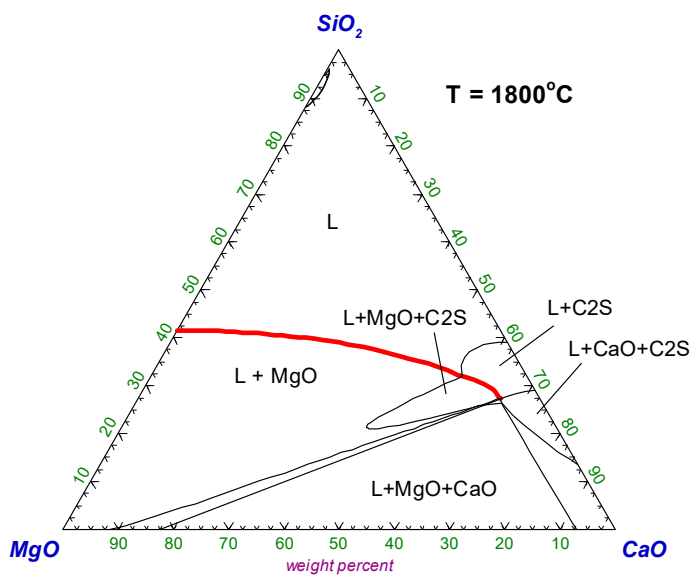

(d)

Figure 2. Calculated phase diagrams of the $\mathrm{CaO}-\mathrm{MgO}-\mathrm{SiO} 2-5 \% \mathrm{Al}_{2} \mathrm{O}_{3}-5 \% \mathrm{Cr}_{2} \mathrm{O}_{3}$ at $\mathrm{P}\left(\mathrm{O}_{2}\right)=10^{-9}$ atm. (a) 1500, (b) 1600, (c) 1700 and (d) $1800^{\circ} \mathrm{C}$ by FactSage (reproduced from [13], with permission from authors, 2016) Oliv $=\mathrm{Mg}_{2} \mathrm{SiO}_{4}$-rich olivine solution, $\mathrm{Sp}=\mathrm{Mg}(\mathrm{Cr}, \mathrm{Al})_{2} \mathrm{O}_{4}$ spinel solution, $\mathrm{C} 2 \mathrm{~S}=\mathrm{Ca}_{2} \mathrm{SiO}_{4}$ solution, $\mathrm{MgO}=\mathrm{MgO}$-rich solution, $\mathrm{CaO}=\mathrm{CaO}$-rich solution, $\mathrm{C} 3 \mathrm{MS} 2=\mathrm{Ca}_{3} \mathrm{MgSi}_{2} \mathrm{O}_{8}, \mathrm{Cor}=(\mathrm{Cr}, \mathrm{Al})_{2} \mathrm{O}_{3}$ corundum solution. Thick red lines represent the $\mathrm{MgO}$-rich solid saturation line. It should be noted that the axis of Gibbs triangle diagram is re-normalized in term of $\mathrm{CaO}+\mathrm{MgO}+\mathrm{SiO}_{2}=100$ wt. $\%$.

It is important to realize that slag compositions with $\mathrm{SiO}_{2}<25 \%$ are not relevant for stainless steel slags (Table 1). Therefore, the complex phase assemblages with $\mathrm{SiO}_{2}<25 \%$ in Figure 2 are of lower importance. Saturation lines of $\mathrm{MgO}$ (thick red lines in Figure 2) are important in order to minimize corrosive wear of the MgO-based EAF hearth lining and sidewalls of EAF, ladle or AOD by approaching $\mathrm{a}_{\mathrm{MgO}}=1$. It is interesting to note that the $\mathrm{MgO}$ saturation line is rather robust against temperature (Figure 2) and also against variations of oxygen activity. This behaviour is very similar to the $\mathrm{MgO}$ saturation in the system $\mathrm{MgO}-\mathrm{CaO}-\mathrm{FeO}-\mathrm{SiO}_{2}$ for carbon steel slags [12]. The $\mathrm{MgO}$ level of the slag depends on the addition of $\mathrm{MgO}$-bearing slag former besides lime, e.g., doloma. At significantly undersaturated $\mathrm{MgO}$ slag composition, the dissolution of the $\mathrm{MgO}$ hearth lining may increase the $\mathrm{MgO}$ content of the slag until saturation is achieved. The saturation field of $\mathrm{C}_{2} \mathrm{~S}$ is important in order to control the $\mathrm{C}_{2} \mathrm{~S}$ component in the cooled stainless steel slag. According to the calculated diagram, $\mathrm{Mg}(\mathrm{Cr}, \mathrm{Al})_{2} \mathrm{O}_{4}$ spinel solution appears in $\mathrm{MgO}$-saturation region until $1700{ }^{\circ} \mathrm{C}$. The amount of spinel solid is about $5 \mathrm{wt}$ \% of the entire slag due to limited amount of $\mathrm{Cr}_{2} \mathrm{O}_{3}(5 \%)$ used in the calculation. 
This means when the slag is $\mathrm{MgO}$ saturated, about $5 \%$ of solid spinel phase can exist in slag as a solid phase.

The calculated phase assemblages with varying $\mathrm{Cr}_{2} \mathrm{O}_{3}$ content from $3 \%$ to $10 \%$ at $1600{ }^{\circ} \mathrm{C}$ and $1700{ }^{\circ} \mathrm{C}$ are presented in Figure 3. In the diagram, only $\mathrm{MgO}$ saturation and $\mathrm{C}_{2} \mathrm{~S}$ saturation lines are plotted in order to see the variation of these saturation lines with $\mathrm{Cr}_{2} \mathrm{O}_{3}$ content. The amount of $\mathrm{Cr}_{2} \mathrm{O}_{3}$ influences the amount and stability of $\mathrm{Mg}(\mathrm{Cr}, \mathrm{Al})_{2} \mathrm{O}_{4}$ spinel, but the saturation lines of $\mathrm{MgO}$ and $\mathrm{C}_{2} \mathrm{~S}$ are rather robust against $\mathrm{Cr}_{2} \mathrm{O}_{3}$ variations. Variations of $\mathrm{Al}_{2} \mathrm{O}_{3}$ on the saturation lines are of less importance as the range of $\mathrm{Al}_{2} \mathrm{O}_{3}$ compositions is close to $5 \%$ in stainless steelmaking slag ( $4 \%$ to $6 \%$ in Table 1).

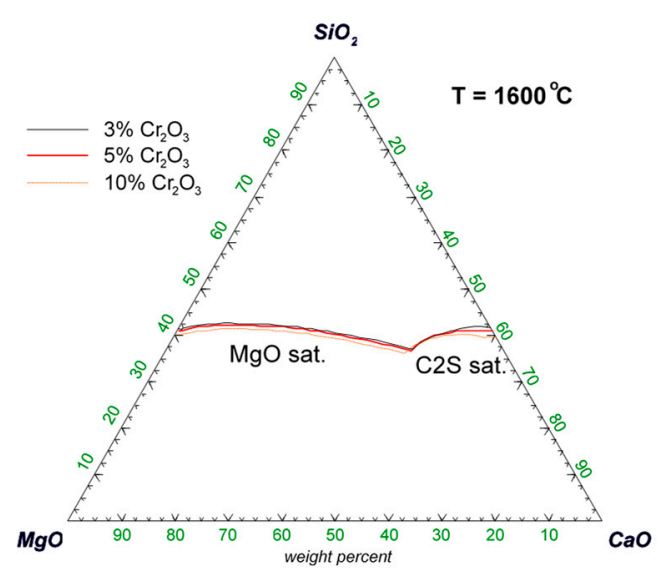

(a)

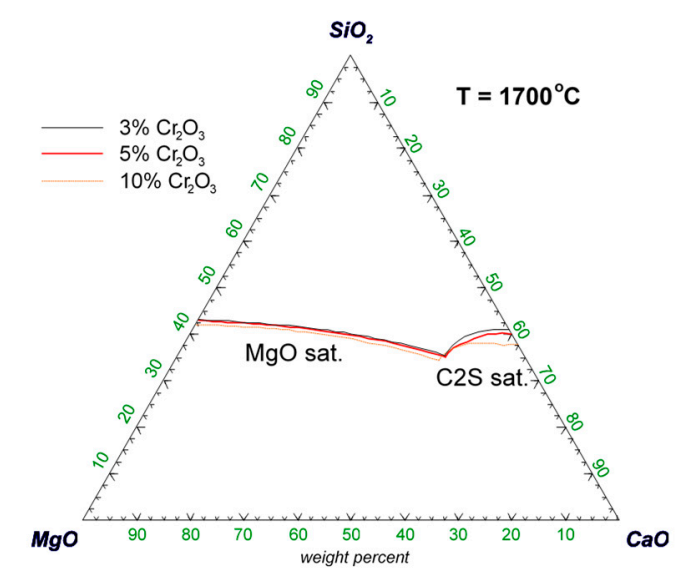

(b)

Figure 3. Calculated $\mathrm{MgO}$ and $\mathrm{C}_{2} \mathrm{~S}$ saturation lines of the $\mathrm{CaO}-\mathrm{MgO}-\mathrm{SiO}_{2}-5 \% \mathrm{Al}_{2} \mathrm{O}_{3}-\mathrm{Cr}_{2} \mathrm{O}_{3}$ system with $3 \%$ to $10 \% \mathrm{Cr}_{2} \mathrm{O}_{3}$ at $\mathrm{P}\left(\mathrm{O}_{2}\right)=10^{-9}$ atm. (a) $\mathrm{T}=1600{ }^{\circ} \mathrm{C}$ and (b) $1700{ }^{\circ} \mathrm{C}$.

\section{Results: Application to Slag Analysis Data from Stainless Steelmaking}

As shown in the previous sections, the phase diagrams in Figures 2 and 3 can be applied with reasonable precision to the analysis of EAF slag data at tapping that show a range of $\mathrm{Cr}_{2} \mathrm{O}_{3}$ between $3 \%$ and $10 \%$ at typical tapping temperatures between $1600{ }^{\circ} \mathrm{C}$ and $1700{ }^{\circ} \mathrm{C}$. In contrast to the $\mathrm{MgO}$ and $\mathrm{C}_{2} \mathrm{~S}$ saturation lines, the portion of $\mathrm{Mg}(\mathrm{Cr}, \mathrm{Al})_{2} \mathrm{O}_{4}$ spinels and $(\mathrm{Cr}, \mathrm{Al})_{2} \mathrm{O}_{3}$ depends more sensitively on temperature and oxygen activity. However, details about the amount of spinels in the slag, i.e., the saturation degree, are of less importance here because these EAF process conditions (temperature distribution, oxygen fugacity) are still difficult to measure in the EAF and to control or adapt at a given EAF design.

As mentioned above, $\mathrm{MgO}$ saturation line in the slag system is important for the corrosion of $\mathrm{MgO}-$ based refractory in stainless steelmaking process. In order to monitor the saturation of $\mathrm{MgO}$ periclase and $\mathrm{C}_{2} \mathrm{~S}$ at tapping temperature, i.e., $1600^{\circ} \mathrm{C}$ to $1700^{\circ} \mathrm{C}$, the phase diagram in Figure 3 can be used. Slag compositions from three stainless steelmaking EAFs are plotted in Figures 4-6. It should be noted that these 3 EAFs have different process strategies. 


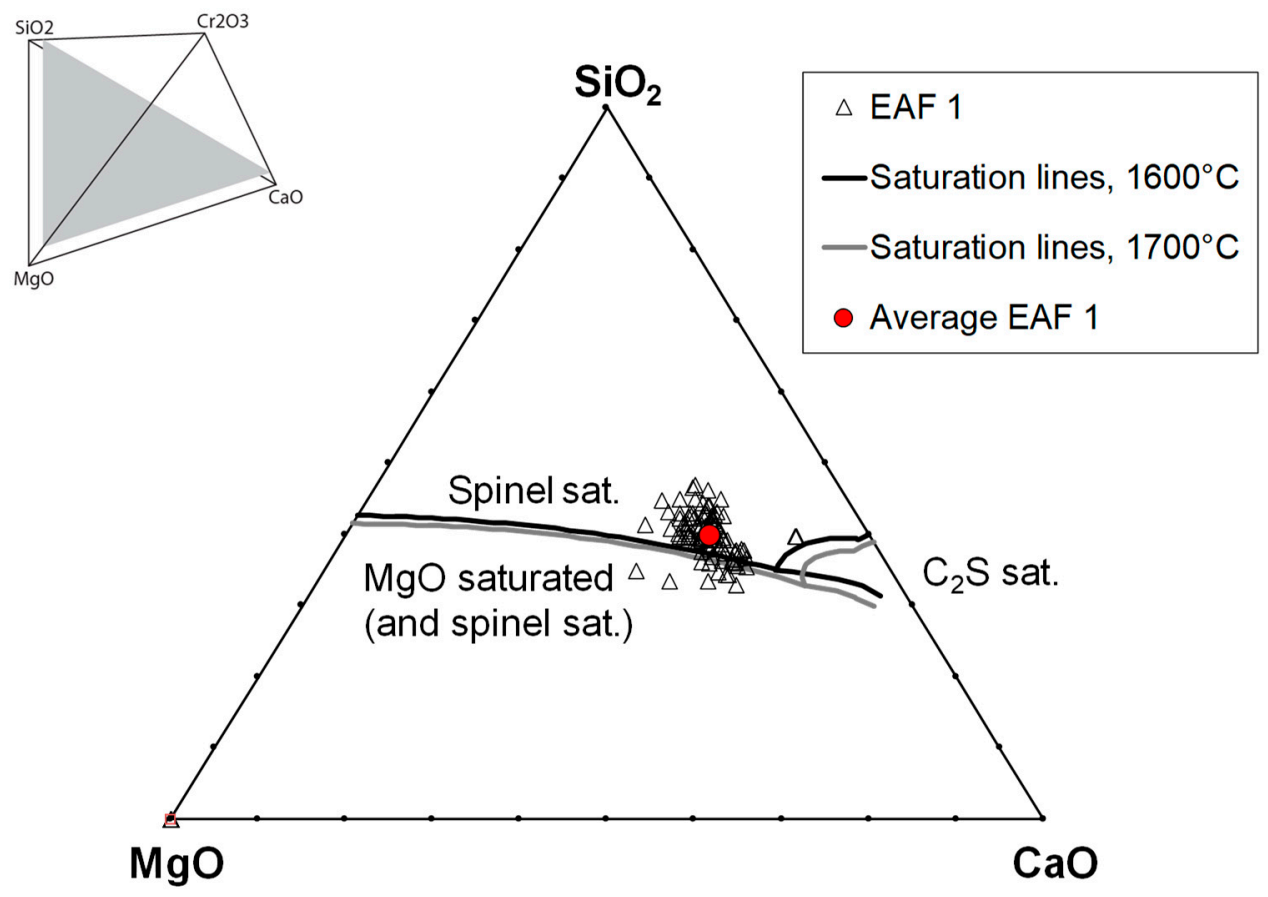

Figure 4. Slag compositions at tapping from EAF 1 versus saturation lines of $\mathrm{MgO}$ and $\mathrm{C}_{2} \mathrm{~S}$. Saturation lines are calculated by FactSage (reproduced from [13]) in the system $\mathrm{CaO}-\mathrm{MgO}-\mathrm{SiO}_{2}-5 \mathrm{wt} \cdot \mathrm{Al}_{2} \mathrm{O}_{3}-3 \sim 10$ wt. $\mathrm{Cr}_{2} \mathrm{O}_{3}$ at $1600{ }^{\circ} \mathrm{C}$ and $1700{ }^{\circ} \mathrm{C}$ (see Figure 3).

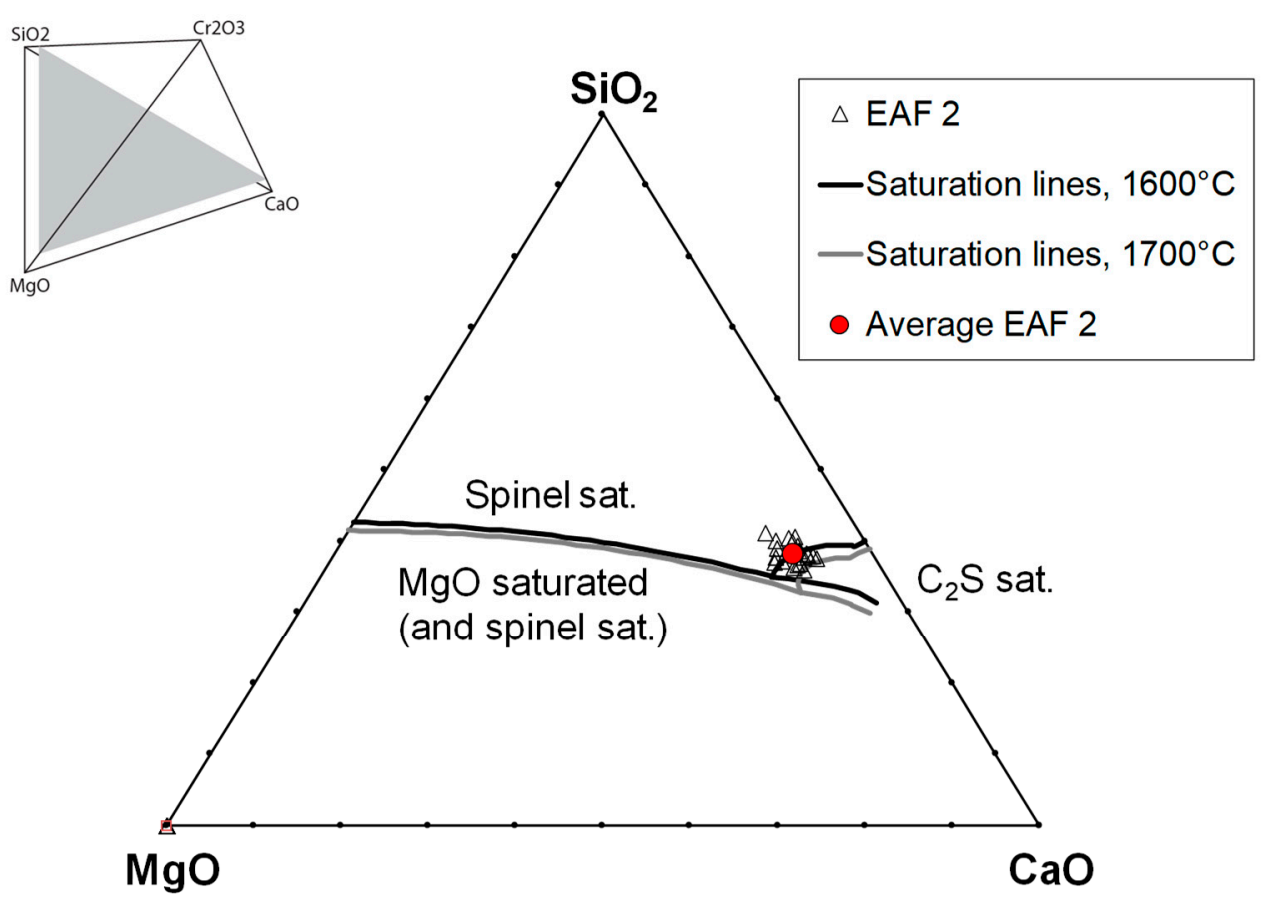

Figure 5. Slag compositions at tapping from EAF 2 versus saturation lines of $\mathrm{MgO}$ and $\mathrm{C}_{2} \mathrm{~S}$. Saturation lines are calculated by FactSage (reproduced from [13]) in the system $\mathrm{CaO}-\mathrm{MgO}-\mathrm{SiO}_{2}$ 5wt. $\mathrm{Al}_{2} \mathrm{O}_{3}-3 \sim 10 \mathrm{wt} . \mathrm{Cr}_{2} \mathrm{O}_{3}$ at $1600{ }^{\circ} \mathrm{C}$ and $1700{ }^{\circ} \mathrm{C}$ (see Figure 3). 


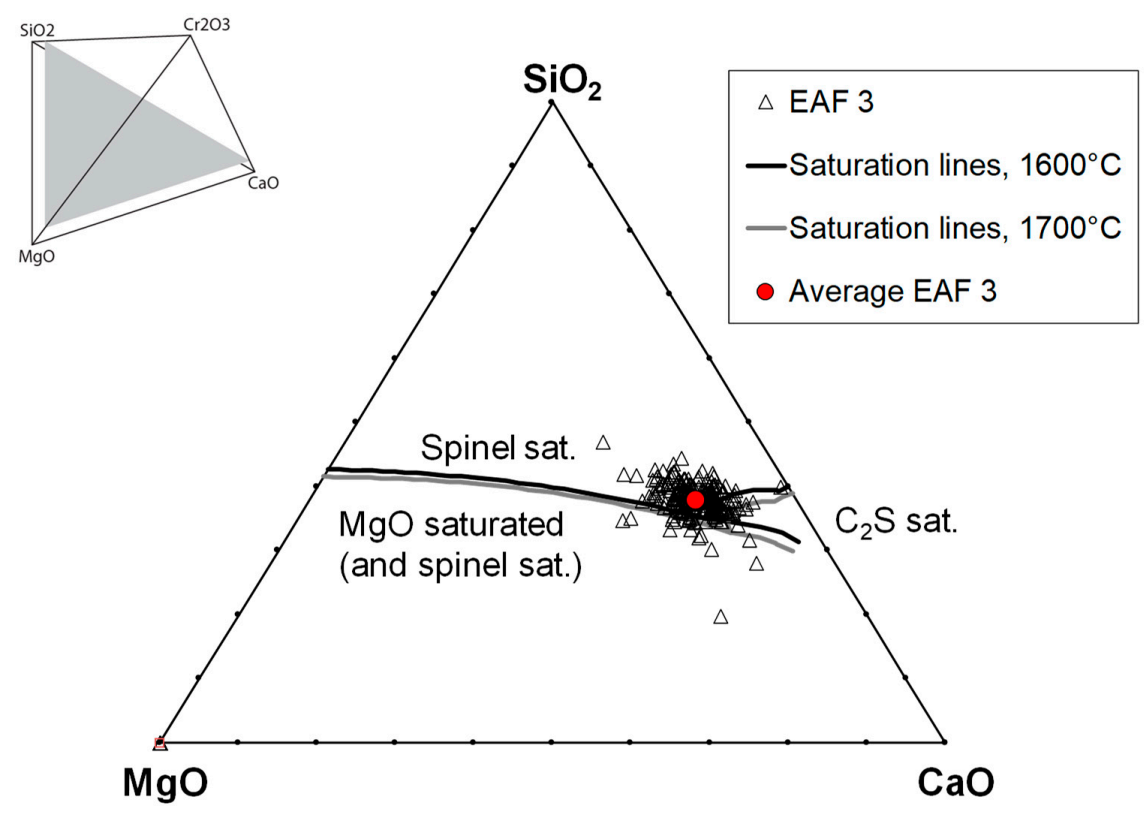

Figure 6. Slag compositions at tapping from EAF 3 versus saturation lines of $\mathrm{MgO}$ and $\mathrm{C}_{2} \mathrm{~S}$. Saturation lines are calculated by FactSage (reproduced from [13]) in the system $\mathrm{CaO}-\mathrm{MgO}-\mathrm{SiO}_{2}$ 5wt. $\mathrm{Al}_{2} \mathrm{O}_{3}-3 \sim 10 \mathrm{wt} . \mathrm{Cr}_{2} \mathrm{O}_{3}$ at $1600{ }^{\circ} \mathrm{C}$ and $1700{ }^{\circ} \mathrm{C}$ (see Figure 3).

\section{Discussion}

The EAF slags of this study are over-saturated with spinel phase (that is, spinel solids are floating on liquid slag). Most of the slags are saturated with $\mathrm{MgO}$ periclase or are close to periclase saturation. This is expected due to $\mathrm{MgO}$ addition with dololime and dissolution from the $\mathrm{MgO}$ hearth and sidewall lining depending on slag temperature and process time, which is very similar to carbon steelmaking slags in the very different system $\mathrm{CaO}-\mathrm{MgO}-\mathrm{SiO}_{2}-\mathrm{FeO}_{\mathbf{x}}$ [12]. The information about the portion of $\mathrm{MgO}$ oversaturated or undersaturated slags at tapping can be used to adjust the input of magnesia-bearing slag formers in order to minimize corrosion of the lining and specific refractory costs, and to maximize lining lifetime.

Published slag diagrams for carbon steelmaking slags (e.g., isothermal stability diagrams [1] or phase equilibrium diagrams [12]) are not appropriate for Cr stainless steelmaking due to the different $\mathrm{FeO}$ content. The proposed diagram in Figures $4-6$ can be applied at the stainless steel plants in order to monitor the slag operation, to check strategy of slag operation and to adjust slag former addition.

The comparison of three EAF operations in Figure 4 to Figure 6 clearly shows that the slags are quite different in terms of $\mathrm{C}_{2} \mathrm{~S}$ saturation. The monitor and control of the EAF slag compositions to $\mathrm{C}_{2} \mathrm{~S}$ saturation is manageable because the slag composition with respect to $\mathrm{CaO}, \mathrm{SiO}_{2}$, and $\mathrm{MgO}$ can be determined from raw material input and mass balance calculations. The $\mathrm{C}_{2} \mathrm{~S}$ saturation is important for the refining capacity of slags, but it can cause the disintegration of solidified slag.

EAF 1 is operating at the $\mathrm{MgO}$ saturation but with a clearly defined distance to $\mathrm{C}_{2} \mathrm{~S}$ saturation which represents a valorised use of the tapped EAF slag (Figure 4). This is achieved by a rather low $\mathrm{CaO}$ level and $\mathrm{CaO} / \mathrm{SiO}_{2}$ basicity (1.04, Table 1). However, the $\mathrm{Cr}_{2} \mathrm{O}_{3}$ activity is kept a high level by applying an increased $\mathrm{MgO}$ input in order to keep sufficiently high $(\mathrm{CaO}+\mathrm{MgO}) /\left(\mathrm{SiO}_{2}+\mathrm{Al}_{2} \mathrm{O}_{3}\right)$ basicity $(1.26$, Table 1). Increased $\mathrm{MgO}$ input also helps to minimize corrosion of the magnesia refractory lining.

EAF 2 operates at lower spinel saturated levels and with a clearly increased amount of oxide liquid, i.e., with better foaming slags, but very close to $\mathrm{C}_{2} \mathrm{~S}$ saturation (Figure 5). Remarkably, the slags of EAF 2 are not $\mathrm{MgO}$ saturated. This corresponds to a doloma hearth lining (as alternative to a magnesia lining), which shows minimum corrosion with $\mathrm{CaO}$-rich slags. The $\mathrm{C}_{2} \mathrm{~S}$ saturated slag can be disintegrated during the solidification, and it would be most probably dumped [11]. Therefore, 
this disadvantage of the $\mathrm{C}_{2} \mathrm{~S}$ saturated slag is balanced by a cost-effective doloma hearth lining in combination with an EAF process slag with improved foaming index.

EAF 3 is operating with a significantly larger variation in slag compositions ranging from $\mathrm{C}_{2} \mathrm{~S}$ saturated slags to $\mathrm{MgO}$-oversaturated slags far from $\mathrm{C}_{2} \mathrm{~S}$ saturation (Figure 6). The large variation in slag composition indicates lower process control on raw materials and EAF process conditions. Also the large portion of $\mathrm{MgO}$ undersaturated slags at tapping is subject to improvement. Measures to increase the process control of EAF no. 3 with focus on the slag composition can also be efficiently monitored by the given slag diagram in Figures 4-6.

The distribution of the analysed slag compositions at tapping with respect to the $\mathrm{MgO}$ and $\mathrm{C}_{2} \mathrm{~S}$ saturation diagrams is more informative than the average value of the samples, because even some portions of heats with inappropriate slag control may increase wear rate of the lining or affect the capability of EAF slags for deposit in accordance with environmental regulations.

\section{Conclusions}

Control of the slag composition at EAF tapping of $\mathrm{Cr}$-bearing stainless steel grades is crucial in order to minimize corrosion of the EAF hearth lining and keep the slag viscosity in a feasible range for slag foaming. In addition, it is important to maximize the valorisation of stainless steel slag by the stabilization of $\mathrm{CrO}_{x}$ in spinels, and to minimize the amount of $\mathrm{C}_{2} \mathrm{~S}$ for deposit characteristics in agreement with high environmental standards.

We present a simplified diagram to monitor slag compositions in EAF stainless steelmaking with focus on saturation figures with $\mathrm{MgO}$ and $\mathrm{C}_{2} \mathrm{~S}$. The diagram was calculated for typical slag compositions in the system $\mathrm{CaO}-\mathrm{MgO}-\mathrm{SiO}_{2}-\mathrm{Al}_{2} \mathrm{O}_{3}-\mathrm{Cr}_{2} \mathrm{O}_{3}$ at tapping conditions using FactSage software and database.

Depending on given EAF process strategy, the control of slags near or at the $\mathrm{C}_{2} \mathrm{~S}$ saturation or with a distinct distance to $\mathrm{C}_{2} \mathrm{~S}$ formation can be monitored and improved. In case of magnesia based EAF hearth linings the $\mathrm{MgO}$ saturation figures of the slags can be efficiently monitored and optimized for minimum refractory wear and maximum lining lifetime with the same diagram.

Author Contributions: Conceptualization, methodology, original draft preparation, M.K.; validation, improved calculations, review, text improvements, I.-H.J.; providing collaboration network, resources G.H. All authors have read and agreed to the published version of the manuscript.

Funding: This research received no external funding. The APC was funded by the German Research Foundation (DFG) and the University of Bayreuth in the funding programme Open Access Publishing.

Acknowledgments: Managers of three steel plants for stainless steel production are kindly acknowledged for providing slag analysis data and permission to publish basic results in an anonymous way.

Conflicts of Interest: The authors declare no conflict of interest.

\section{References}

1. Pretorius, E.B.; Nunnington, R.C. Stainless steel slag fundamentals-From furnace to tundish. Ironmak. Steelmak. 2002, 29, 133-139. [CrossRef]

2. Guo, M.; Durinck, D.; Jones, P.T.; Heylen, G.; Hendrickx, R.; Baeten, R.; Blanpain, B.; Wollants, P. EAF Stainless Steel Refining-Part I: Observational Study on Chromium Recovery in an Eccentric Bottom Tapping Furnace and a Spout Tapping Furnace. Steel Res. Int. 2007, 78, 117-124. [CrossRef]

3. Bažan, J.; Socha, L.; Kurka, V.; Jonšta, P.; Sušovský, M. Increase of chromium yield by slag reduction during production of chromium steels. IOP Conf. Ser. Mater. Sci. Eng. 2017, 179, 1-7. [CrossRef]

4. Mees, H.; Senk, D. Reduzierung von Chromanteilen in E-Ofen-Schlacken durch Steigerung der Legierungsmitteleffizienz bei der Erzeugung von hochchromhaltigen Schmelzen (Decrease of Chromium content in EAF slags by increased efficiency of alloys at the production of high Chromium melts). In Mineralische Nebenprodukte und Abfälle 4-Aschen, Schlacken, Stäube und Baurestmassen; Thomé-Kozmiensky, K.J., Thiel, S., Thomé-Kozmiensky, E., Friedrich, B., Pretz, T., Quicker, P., Senk, D.G., Wotruba, H., Eds.; TK Verlag: Neuruppin, Germany, 2017; ISBN 978-3-944310-35-0. 
5. Kühn, M.; Mudersbach, D.; Baena Liberato, J.M.; De Angelis, V.; Capodilupo, D.; De Fries, U. Chrome Immobilization in EAF Slags from High-Alloy Steelmaking: Development of a Slag Treatment Process; EU report no. 22077-EN; Directorate-General for Research and Innovation: Brussels, Belgium, 2006; ISBN 92-79-02077-3.

6. Kühn, M.; Mudersbach, D. Treatment of liquid EAF-slag from stainless steelmaking to produce environmental friendly construction materials. In Proceedings of the 2nd International Conference on Process Development in Iron and Steelmaking (Scanmet II), Lulea, Sweden, 6-9 June 2004; Volume 2, pp. 369-377.

7. Zhao, Q.; Liu, C.; Cao, L.; Zheng, X.; Jian, M. Effect of Lime on Stability of Chromium in Stainless Steel Slag. Minerals 2018, 8, 424-434. [CrossRef]

8. Albertsson, G.; Teng, L.; Björkman, B.; Seetharaman, S.; Engström, F. Effect of Low Oxygen Partial Pressure on the Chromium Partition in $\mathrm{CaO}-\mathrm{MgO}-\mathrm{SiO}_{2}-\mathrm{Cr}_{2} \mathrm{O}_{3}-\mathrm{Al}_{2} \mathrm{O}_{3}$ Synthetic Slag at Elevated Temperatures. Steel Res. Int. 2013, 84, 670-679. [CrossRef]

9. Zeng, Q.; Li, J.; Mou, Q.; Zhu, H.; Xue, Z. Effect of FeO on Spinel Crystallization and Chromium Stability in Stainless Steel-Making Slag. J. Miner. Met. Mater. Soc. 2019, 71, 2331-2337. [CrossRef]

10. Sano, N. Reduction of Chromium Oxide in stainless steel slags. In Proceedings of the 10th International Ferroalloys Congress, Cape Town, Africa, 1-4 February 2004; pp. 670-677, ISBN 0-9584663-5-1.

11. Pontikes, Y.; Jones, P.T.; Geysen, D.; Blanpain, B. Options to prevent dicalcium silicate-driven disintegration of stainless steel slags. Arch. Metall. Mater. 2010, 55, 1167-1172. [CrossRef]

12. Kirschen, M.; Hanna, A.; Zettl, K.-M. Improvement of EAF process and refractory consumption by advanced slag modelling. Iron Steel Technol. 2016, 13, 52-59.

13. Bale, C.W.; Bélisle, E.; Chartrand, P.; Decterov, S.A.; Eriksson, G.; Gheribi, A.E.; Hack, K.; Jung, I.-H.; Kang, Y.-B.; Melançon, J.; et al. FactSage thermochemical software and databases-2010-2016. Calphad 2016, 54, 35-53. [CrossRef]

14. Mostafee, S. A Study of EAF High-Chromium Stainless Steelmaking Slags Characteristics and Foamability. Ph.D. Thesis, Royal Institute of Technology, Stockholm, Sweden, 2011; p. 66.

15. Morita, K.; Tsukiashi, K.; Kimura, M.; Sano, N. Activity of Chromium Oxide in CaO-SiO 2 based slags at 1873 K. Steel Res. Int. 2005, 76, 279-283. [CrossRef]

16. Dong, P.; Wang, X.; Seetharaman, S. Thermodynamic activity of Chromium Oxide in $\mathrm{CaO}-\mathrm{SiO}_{2}-\mathrm{MgO}^{-} \mathrm{Al}_{2} \mathrm{O}_{3}-$ $\mathrm{CrO}_{x}$ melts. Steel Res. Int. 2009, 80, 202-208.

17. Li, J.; Zeng, Q.; Mou, Q.; Yu, Y. Effect of Basicity on Precipitation of Spinel Crystals in a CaO-SiO $2-\mathrm{MgO}^{-}$ $\mathrm{Cr}_{2} \mathrm{O}_{3}$-FeO System. High Temp. Mater. Proc. 2019, 38, 867-872. [CrossRef]

18. Arnout, S.; Verhaeghe, F.; Blanpain, B.; Wollants, P. A thermodynamic model of the EAF process for stainless steel. In Proceedings of the European Metallurgical Conference, Dresden, Germany, 18-21 September 2005; Volume 3, pp. 1325-1337.

19. Jung, I.-H.; Decterov, S.; Pelton, A.D. Thermodynamic modelling of $\mathrm{MgO}-\mathrm{Al}_{2} \mathrm{O}_{3}-\mathrm{CrO}-\mathrm{Cr}_{2} \mathrm{O}_{3}$ systems. J. Am. Ceram. Soc. 2005, 88, 1921-1928. [CrossRef]

20. Arnout, S.; Guo, M.; Durinck, D.; Jones, P.T.; Blanpain, B.; Wollants, P. Phase relations in stainless steel slags. In Proceedings of the European Metallurgical Conference, Düsseldorf, Germany, 11-14 June 2007; pp. 1931-1946.

21. Jung, I.-H. Overview of the applications of thermodynamic database to steelmaking process. Calphad 2010, 34, 332-362. [CrossRef]

22. Durinck, D.; Jones, P.T.; Guo, M.; Verhaeghe, F.; Heylen, G.; Hendrickx, R.; Baeten, R.; Blanpain, B.; Wollants, P. EAF Stainless Steel Refining-Part II: Microstructural Slag Evolution and its Implications for Slag Foaming and Chromium Recovery. Steel Res. Int. 2007, 78, 125-135. [CrossRef]

23. Arnout, S.; Guo, M.; Jung, I.-H.; Blanpain, B.; Wollants, P. Experimental determination of CaO-CrO-Cr $\mathrm{C}_{2}-$ $\mathrm{MgO}-\mathrm{SiO}_{2}$ and thermodynamic modeling of the $\mathrm{CrO}-\mathrm{Cr}_{2} \mathrm{O}_{3}-\mathrm{MgO}-\mathrm{SiO}_{2}$ system. J. Am. Ceram. Soc. 2009, 92, 1831-1839. [CrossRef]

(C) 2020 by the authors. Licensee MDPI, Basel, Switzerland. This article is an open access article distributed under the terms and conditions of the Creative Commons Attribution (CC BY) license (http://creativecommons.org/licenses/by/4.0/). 